\title{
Надзор за иностранными врачами в Российской империи в первой половине XIX века
}

\begin{abstract}
Аннотачия. Проблема надзора за иностранцами в Российской империи является малоисследованной, из профессиональных групп лишь контроль над иностранньми учителями и гувернерами нашел отражение в историографии. Цели статьи - рассмотреть историю формирования нормативно-правовой базы пребывания иностранных врачей в России в первой половине XIX в., привести конкретнье примеры реализачии надзора в отношении этих специалистов на основе документов III Отделения Собственной его императорского величества канчеларии (ГАРФ), Смоленского губернского правления, канщеларии Смоленского гражданского губернатора и губернской врачебной управы (ГАСО). Акчентировано внимание на том, что главным требованием для работь врачей в России было подтверждение ими своей квалификаиии через прохождение испьтаний в российских спечиализированных заведениях. В связи с заинтересованностью российских властей в привлечении иностранных спечиалистов их стимулировали к освоению русского языка и принятию российского подданства. Чтобы показать логику действий российских властей в отношении врачей-иностраниев, охарактеризованы правительственные решения 1850-х г2. Государственный надзор был направлен на обеспечение здоровъя российских подданных и оказание им квалифицированной медииинской помочи со стороны иностраннъх специалистов.
\end{abstract}

Ключевые слова: надзор, контроль, врачи, медики, иностраниы, иностранные врачи, военнопленнъе, законодательство, Российская империя, ХІХ век.

Annotation. The surveillance of foreigners in the Russian empire is a little-researched historiographical subject, with, among professional groups, only control over foreign teachers and tutors being studied. The aim of the article is to examine the formation history of the regulatory-legal base for foreign doctors' sojourn in Russia in the first half of the 19th century, and to cite concrete examples of surveillance implementation over these professionals on the basis of documents from the Third section of His imperial majesty's Own chancellery (State archive of the Russian Federation), the Smolensk governorate office, the chancellery of the Smolensk civil governor and the governorate medical board (State archive of the Smolensk oblast). The author draws particular attention to the fact that the main requirement for receiving medical practice permission in Russia was the validation of a doctor's qualifications through the passage of exams in Russian specialised facilities. Because of the Russian authorities' interest in attracting foreign specialists, these specialists were encouraged to learn Russian language and to receive Russian citizenship. To justify the logic of the authorities' actions towards doctor-foreigners, the author describes the Russian government's decisions taken during the 1850s. State surveillance was directed at ensuring the health of the Russian citizens and administering them with qualified medical aid from foreign specialists.

Key words: surveillance, control, doctors, medics, foreigners, foreign doctors, prisoners of war, legislation, Russian empire, first half of the 19 th century.

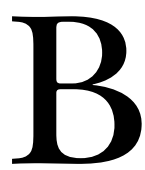

Российской империи осуществлялся надзор за всеми иностранными подданными, находившимися на ее территории. Под этим подразумевалась деятельность государственных органов, наделенных полномочиями по контролю исполнения предписаний законов, иных нормативных актов в отношении иностранцев в целях обеспечения безопасности государства и защиты интересов его подданных. В связи с тем, что врач отвечал за здоровье пациента, российские власти на всех уровнях обязаны были контролировать наличие профессиональных знаний у иностранных докторов, а следовательно, само их право на работу в империи.

Россия в начале XIX в. испытывала недостаток в дипломированных медиках. Особенно остро это проявилось во время военной кампании против Наполеона в 1812 г. К ее началу в русской армии состояло лишь 800-850 лекарей (старших и младших лекарей 1-го и 2-го классов) и 1000-1200 фельдшеров 1-го и 2-го клас- 
сов. Многие штатные медицинские должности оставались вакантными [2, 449]. Для сравнения: медицинский персонал Великой армии Наполеона к началу военных действий на территории России насчитывал 5112 человек (в том числе свыше 2000 хирургов) [2, 452].

Нехватка собственных врачей вынудила российские военные и гражданские власти обратить особое внимание на специалистов из числа военнопленных [9, 80; 16,177$]$. Так, уже в ходе войны оказавшийся в русском плену после сражения под Красным в ноябре 1812 г. медик (в чине капитана 2-го гренадерского полка наполеоновской армии) Доминик де ла Флиз продолжал исполнять свои профессиональные обязанности в отношении своих товарищей-военнопленных $[9,80 ; 2,459]$.

М. И. Кутузов в декабре 1812 г. утвердил право использовать пленных медиков прежде всего для лечения больных пленных, а в случае надобности разрешил им работать в российских госпиталях под надзором военного ведомства. Пленные врачи по своему желанию могли вступить в службу в российскую армию, предварительно подвергшись экзамену главного медицинского инспектора по армии. Военный министр А. И. Горчаков в ответ на обращение главнокомандующего в Санкт-Петербурге, председателя Комитета министров и управляющего Министерством полиции С. К. Вязмитинова в марте 1813 г. предложил распределить военнопленных врачей по госпиталям разных губерний. В Смоленскую губернию, например, рекомендовалось направить 12 пленных медиков (столько же - в Псковскую). Это меньше, чем было направлено в Минскую (26), Виленскую (24), Рязанскую и Владимирскую губернии (по 16), но больше, чем в госпитали других губерний $[16,179]$. Оказывать помощь гражданскому населению иностранным медикам разрешалось только после сдачи экзамена [16, 188].

Реальная же практика была иной в силу экстраординарных обстоятельств, вызванных военными действиями и ситуацией с ранеными и больными сразу после кампании [17, 310; 40 , 300-301; 9, 80-81]. Так, вюртембержец, старший врач 3-го конно-егерского герцога Людовика полка Генрих фон Роос без всякого экзамена с апреля 1813 по январь 1814 г. был уездным доктором в г. Борисове Минской губернии [17, 307308], а французский хирург Дезире Фюзейе с ноября 1813 по июнь 1814 г. врачевал в уездном городе Спасске Казанской губернии [40, 300-301].
Известно, что в Харьковской губернии, согласно предписанию губернатора, польские лекари Фердинанд Вагнер и Симон Свитковский были испытаны врачебной управой. В результате выяснилось, что «Вагнер сведущ довольно в производстве врачебной практики, а Свитковский посредственно» [29, 147].

По разрешению хозяев пленные оказывали медицинскую помощь крепостным крестьянам в сельской местности. Уже упоминавшийся Доминик де ла Флиз лечил нуждающихся в имении Белая Церковь Киевской губернии, принадлежавшем графине А. В. Браницкой. Только в 1815 г. Д. де ла Флиз успешно сдал әкзамен на степень лекаря в Московском отделении Медико-хирургической академии [9, 80-81].

Многие российские помещики пользовались помощью пленных медиков, не прошедших квалификационных испытаний в России. В Смоленской губернии итальянец, лекарь в походных госпиталях наполеоновской армии Франсуа Палиари (или Пальери), занимался врачебной практикой в селе Мошенец Рославльского уезда Смоленской губернии, принадлежавшем штабскапитану А. Лешевич-Бородуличу. Иностранец заслужил такое уважение владельца, что тот стал мечтать о заведении госпиталя и аптеки под началом итальянского медика [20, л. 21]. В отношении главнокомандующего в г. Санкт-Петербурге С. К. Вязмитинова смоленскому гражданскому губернатору от 28 февраля 1814 г. за № 59 предписывалось: «Вследствие представления вашего превосходительства от 29 прошедшего генваря о желании, объявленном пленным лекарем Палиари вступить в подданство России и производить врачебную практику, я прошу вас объявить врачу сему, что для получения права на отправление врачебной практики в России он должен выдержать экзамен в ближайшем российском университете, для чего ваше превосходительство можете снабдить его надлежащим на проезд паспортом» [42, л. 214].

Были и другие медики из числа военнопленных, которые остались в России, успешно прошли испытания в Императорской медикохирургической академии и работали на Смоленщине: уроженец Вестфалии, пленный врач Каспер Вильгельм Либерт, лечивший в имении действительной статской советницы Рибопьер в Вяземском уезде, а затем получивший свидетельство штаб-лекаря в академии $[6,31 ; 41$, л. 250]; французский пленный Франц Иванович Валь, который выполнял хирургические опера- 


\section{Исторический журнал: научные исследования № 4 (22) • 2014}

DOI: $10.7256 / 2222-1972.2014 .4 .13937$

ции в русской армии, а в 1815 г. академией был признан лекарем 3-го отделения (т. е. хирургом) и в дальнейшем стал известным смоленским врачом [28], и др.

Еще 31 декабря 1813 г. высочайше утвержденным Положением о приеме в российскую военно-медицинскую службу иностранных врачей они («всех наций и всякого звания») приглашались на время военной кампании «для определения в армию по полкам и временным госпиталям». Иностранные медики разделялись на три класса: 1) доктора медицины и хирургии или лекари, знающие анатомию, физиологию, патологию, терапию, хирургию, ботанику, химию, физику, повивальное искусство и судебную медицину, способные лечить внутренние болезни и производить хирургические операции; 2) доктора или лекари, лечившие внутренние болезни, но не занимавшиеся хирургией; 3) «подлекари, находящиеся большею частью в Германии, где они известны под названием хирургов, т. е. обучавшиеся только анатомии, физиологии и практической хирургии и знающие латинский язык в такой мере, чтобы могли удобно разбирать рецепты в латинских фармакопеях и писать оные правильно» [21, № 25508].

От принадлежности к определенному разряду медика зависел размер его жалованья, а от времени службы - возможность получения и размер пенсиона. Иностранный врач мог всегда получить отставку и выехать из России, исключая лишь время военных действий.

Медики-иностранцы, желавшие поступить на российскую службу, обязаны были явиться к главному по армии медицинскому инспектору или полевому генерал-штаб-доктору. При невозможности этого - предъявить свои свидетельства военным начальникам ближайших корпусов, дивизий или отрядов, а те, в свою очередь, должны были направить их на рассмотрение главному по армии медицинскому инспектору. Этот чиновник или его доверенное лицо должен был подвергнуть иностранных медиков «испытанию во врачебной науке», в соответствии с результатами которого определялись класс медика и его дальнейшее назначение. Изготавливались соответствующие дипломы, которые вручались иностранцам Медицинским департаментом Военного ведомства. Принятые на службу врачи приводились к присяге, а их присяжные листы отсылались в Медицинский департамент. Гражданские медики из числа иностранцев могли не спешить с принятием российского подданства, но этим правом часто пользовались и врачи из числа пленных. Например, Ф. И. Валь принес присягу на верность Российской империи лишь в 1837 г. [18, л. 34об.], т. е. после 25 лет проживания на территории империи.

С учреждением в 1826 г. III Отделения Собственной его императорского величества канцелярии надзор в отношении иностранных подданных, в т. ч. и врачей, усилился. 7 апреля 1827 г. начальник Главного штаба в СанктПетербурге информировал шефа жандармов графа А. Х. Бенкендорфа, что «его императорскому величеству благоугодно, дабы со всех пограничных мест империи присылаемы были в III Отделение Собственной его величества канцелярии семидневные ведомости обо всех прибывающих в Россию иностранцах как к портовым городам, так равно и чрез сухопутные заставы, и чтобы таковые ведомости представлялись к высочайшему воззрению» [1, л. 1]. Ведомости представляли собой таблицу с указанием: 1) порядкового номера иностранца в списке; 2) его имени, фамилии и звания; 3) национальности («нации») или подданства; 4) «откуда прибыл и с каким паспортом»; 5) цели («предмета») приезда [1, л. 537]. В III Отделение должны были передаваться национальные паспорта иностранцев, которые прежде оставались в губернских правлениях. Это положение было отражено затем и в Своде законов Российской империи [31, ст. 343].

Чтобы закрыть вакантные места военных медиков, согласно Сенатскому указу от 29 декабря 1827 г. («с прописанием высочайшего повеления») «О правилах для принятия приглашаемых на службу в военно-сухопутное и морское ведомство, как иностранных врачей, так и врачей, в России находящихся, из отставных и неслуживших» иностранные врачи вызывались именно в военные, а не в гражданские ведомства.

Иностранные медики обязаны были представить свидетельства о поведении и аттестаты тех учебных заведений, где обучались профессии. В зависимости от знаний они разделялись на два разряда: 1) сведущие «во всей врачебной науке», они должны были знать латынь и подвергались экзамену по широкому спектру знаний, а потом могли занимать высшие должности; 2) те, которые не занимались хирургией, но имели основательные знания во врачебной науке, обязаны были знать латынь, но только в прикладном плане (для написания рецептов).

Для поступления на службу и прохождения испытаний желающим следовало прибыть 
в Петербург в Медицинский департамент Военного министерства или к флотскому генералштаб-доктору для распоряжения об экзаменах и месте назначения. Экзамены проводились попрежнему в Медико-хирургической академии с выдачей аттестата. В соответствии с результатом испытаний определялись размер жалованья, место службы и право на пенсион - в зависимости от времени службы. Для обучения русскому языку «экзаменованные» медики должны были год проработать в госпитале, а чтобы рассчитывать на пенсион, обязывались прослужить 12 лет [22, № 1664]. 22 октября 1828 г. последовал именной указ Николая I, отменявший вызов иностранных врачей на военно-сухопутную и морскую службу, так как «в армии собственные $<\ldots>$ врачи в достаточном числе находятся» [23, № 2366]. Вероятнее всего, такое решение было продиктовано не столько реальным заполнением штатов отечественными медиками, сколько соображениями безопасности. Интересным является и то, что в том же 1828 г. III Отделение продолжало осуществлять курирование вопроса «о вызванных из-за границы медиках для вступления в российскую службу» [10, 241].

20 июня 1829 г. именным указом иностранцы, знавшие латынь, допускались к экзамену на фармацевтические звания в Императорской медико-хирургической академии и в ее Московском отделении. Аптекари и провизоры, желавшие содержать вольные аптеки, должны были подвергнуться испытанию не только в латыни, русском, но и желательно еще в каком-то европейском языке (немецком, французском и проч.) [24, № 2944]. Документы, выданные зарубежными заведениями и полученные по итогам экзаменов в России, иностранным медикам отдавали на руки [24, № 3218], что было важно при занятиях ими «вольной практикой» либо в случае отъезда за границу.

Надзорные мероприятия в отношении иностранцев «во вверенной» ему территории осуществлял губернатор как представитель государя, а информировала его о выявленных нарушениях врачебная управа. Так, в 1831 г. Смоленская врачебная управа уведомила губернатора, что в Духовщинском уезде проживает подпоручик Николай Прейс, который «выдает себя за вольнопрактикующего медика и, не имея на то никакого права, занимается зловредным лечением людей», и начальник губернии 14 августа 1831 г. дал необходимые предписания духовщинскому исправнику: «Отыскав непременно помянутого шарлатана Прейса, выслать его в здешнюю врачебную управу для поступления с ним по законам и о последующем донести» $[17$, л. 820]. Согласно российскому законодательству Прейс должен был быть выслан за границу. Прецеденты уже были: именной указ Николая I, объявленный 6 декабря 1827 г. управляющему Министерством внутренних дел санкт-петербургским военным генерал-губернатором, красноречиво назывался: «О высылке прусского подданного Дитриха, выдающего себя за врача, как обманщика за границу и о поступании впредь таким же образом при подобных случаях» [22, № 1601].

Согласно высочайше утвержденному 19 января 1832 г. мнению Государственного совета «в российскую действительную службу по учебной и искусственной частям» медики, выдержавшие экзамен и удостоенные медицинских или аптекарских званий, могли приниматься лишь после принятия подданства России [25, № 5087].

В провинции дипломированные врачи были наперечет, поэтому их появление становилось событием, достойным объявления в губернских газетах (обязательно с ведома полиции). На страницах «Смоленских губернских ведомостей» за июнь 1838 г. можно прочесть информацию о новом смоленском докторе: «Число наших врачей умножилось: сюда приехал со своим семейством из Псковской губернии на всегдашнее жительство из иностранцев доктор медицины Сентимер, врач немолодых лет, который обучался медицине в Венском университете в Австрии и в Париже и уже двадцать четыре года по экзамену имеет диплом русского доктора медицины» $[34,124]$. Полное имя врача - Флориан Флорианов Сентимер. Это удалось узнать из его прошения о сыне, направленного в августе 1838 г. директору народных училищ Смоленской губернии [30, л. 20].

В прошлом Флориан Сентимер (ок. 1786 между 1836-1847) являлся военным врачом в наполеоновской армии, попал в русский плен в 1812 г., затем лечил раненых в госпиталях Орла. В 1814 г. вступил в подданство России, за службу получил право на дворянство и в 1824 г. был внесен в 3-ю часть дворянской родословной книги Московской губернии [5, 580]. В 1821-1825 гг. он состоял при Управлении округа Главного управления путей сообщения $[11,904 ; 12,718$; 13, 740; 14, 772; 15, 765].

К моменту переезда в Смоленск Сентимер был уже известным вольнопрактикующим врачом в Москве. Он обращался к российскому пра- 


\section{Исторический журнал: научные исследования № 4 (22) • 2014}

DOI: $10.7256 / 2222-1972.2014 .4 .13937$

вительству с просьбой о предоставлении денежного пособия для издания собственного сочинения о холере [10, 248]. Действительно, в 1833 г. в университетской типографии в Москве он издал работу «Еще нечто о холере» [32]. Позже другое его сочинение вышло в свет на немецком языке в Лейпциге в 1836 г. [5, 580] и было переиздано на русском языке под названием «Холера излечима!» в 1872 г. [33].

Еще один смоленский врач «из иностранцев» - Александр Францев Селю, выпускник Московского университета 1823 г., сдавший экзамен на степень лекаря 1-го отделения. Он служил в Московском госпитале, а затем - при Белевском пехотном полку. Работал врачом в условиях боевых действий в 1831 г. во время подавления польского восстания. В 1833 г. Селю получил чин коллежского асессора и занимал должность поречского городового врача до своей смерти в августе 1858 г. [38, л. 1-8].

Не менее десяти лет рославльским городовым врачом (1849-1859) служил бывший баденский подданный Август Иванович Дурлахер (ок. 1778 - после 1859). Будучи выпускником медицинского факультета Гейдельбергского университета, он получил право быть вольнопрактикующим врачом и акушером. 19 января 1846 г. Дурлахер успешно сдал экзамен в Московской медико-хирургической академии, а 21 сентября 1849 г. был принят на должность городового врача в Рославле. Этому событию предшествовало принесение Дурлахером присяги на верность России в Смоленском губернском правлении 23 августа 1849 г. [37, л. 4-5; 36, л. 1-2]. Российское правительство было заинтересовано в иностранных медиках как специалистах, а принятие ими российского подданства служило гарантией благонадежности.

Характерно, что, зная о существовавшем в России надзоре, некоторые иностранные медики не решались сдавать в империи соответствующий экзамен, что не позволяло им стать практикующими специалистами, они могли быть лишь приживалами у богатых российских вельмож и лекарями для их крепостных. Один из подобных примеров упоминает в своих «Записках» граф М. Д. Бутурлин. В доме генерал-майора Николая Андриановича Дивова в Городище Рязанской губернии мемуарист в 1848 г. познакомился с уроженцем Страсбурга Корнелием Павловичем Бестом. Тот был хирургом в наполеоновской армии в начале XIX в. и после 1815 г. приехал в Россию, где 20 лет был домашним медиком князя
Е. А. Грузинского, а затем поселился у Н. А. Дивова. По словам М. Д. Бутурлина, авторитетный московский врач А. И. Овер так отзывался об иностранце: «Пред медицинскими познаниями г-на Беста мы все должны шапки скидывать» [8, 148]. В то же время тот не решился сдавать университетский экзамен, кроме того, несмотря на сорокалетнее пребывание в России, не мог свободно говорить по-русски. Не имея свидетельства, К. П. Бест «не дерзал написать никакого рецепта», а если по чьей-то просьбе и решался рекомендовать лекарство, то был вынужден писать записочки знакомому аптекарю в виде личной просьбы $[8,148]$.

Упоминаемый выше Александр Иванович Овер (1804-1864) был из семьи французских эмигрантов, но родился в России и учился в Москве (в Медико-хирургической академии и Московском университете), где впоследствии сам преподавал и заведовал клиниками. Стал автором известного четырехтомного атласа «Selecta praxis medicochirurgicae» (1847-1852), принесшего ему европейскую известность. Занимал должность инспектора московских больниц гражданского ведомства и дослужился до чина тайного советника. Этот выдающийся хирург признан одним из основоположников клиникоанатомического направления в отечественной медицине [19].

Из знаменитых врачей-иностранцев, работавших в России в рассматриваемый период, следует отметить уроженца Пруссии Федора (Фридриха) Карловича Удена (1754-1823), ставшего впоследствии профессором патологии и терапии Медико-хирургической академии, автором терапевтического руководства «Академические чтения» (в 7 томах, 1816-1822) [35]. Не менее знаменитое имя в истории российской медицины - основоположник первой отечественной научной хирургической школы Иван Федорович Буш (1771-1839). Он был выходцем из немецкой семьи, уроженцем Нарвы и выпускником Петербургского клинического хирургического института, стал профессором Петербургской медико-хирургической академии и автором первого российского обобщающего труда по хирургии «Руководство к преподаванию хирургии» [4]. $\Phi$. К. Уден и Ф. И. Буш были вполне заслуженно удостоены звания академиков Императорской медико-хирургической академии [3, 88].

В 1850-е гг. в отношении иностранных врачей принимались некоторые значимые решения. Так, высочайше утвержденным 7 ноября 
1851 г. положением Комитета министров «О дозволении иностранным врачам продолжать службу на основании общих положений по медицинской части в России» было подтверждено, что новый вызов иностранных врачей для армии и флота не требуется. Однако в связи с продолжением работы врачей-иностранцев, не принявших присягу, начальнику Главного морского штаба следовало в каждом конкретном случае обращаться с представлением в Комитет министров [26, № 25723]. Для иностранных врачей, поступивших на службу в период Крымской войны 1853-1856 гг., было сделано исключение. Их было разрешено принимать без экзаменов в лекари на основе уже имеющихся документов, удостоверявших познания в медицине. Экзамен требовалось сдавать только на звание доктора.

В именном указе Александра II, объявленном Сенату военным министром 26 мая 1857 г., подчеркивалось, что «на будущее время, в случае вызова иностранных врачей в нашу службу по военным обстоятельствам, означать в контракте, что они определяются на службу <... лишь на военное время; что по окончании войны действие контракта совершенно прекращается и все они будут уволены от службы» [27, № 31879]. Врачи-иностранцы, желавшие работать в России, теперь «обязаны непременно достаточно [знать] русский язык и выдержать әкзамен установленным порядком <..> на степень доктора или лекаря в Медико-хирургической академии или в одном из <..> [российских] университетов» [27, № 31879]. Это новое требование свидетельствовало, что правительство, с одной стороны, стремилось иметь иностранных специалистов на длительный срок и стимулировало их к культурной адаптации в России, с другой стороны, требуя знания русского языка, ограничивало круг иностранцев, желавших работать в Российской империи.

\section{Библиография:}

1. Алфавит дел прибывших в Россию иностранцев. 1827-1830 гг. // Государственный архив Российской Федерации. Ф. 109. Оп. 226. Д. 7.

2. Баранов А. А. Медицинская служба российской армии. Медицинская служба французской армии // Отечественная война 1812 года: Энциклопедия / Рук. авторского коллектива В. М. Безотосный. М.: РОССПЭН, 2004. С. 449-452.

3. Будко А. А. История медицины Санкт-Петербурга XIX - начала XX в. СПб.: Нестор-История, 2010. 400 с.

4. Буш Иван Федорович // Мирский М. Б. Медицина России XVI-XIX веков. М.: РОССПЭН, 1996. С. 181-188.

5. Евсеева М. К. Сентимер, Сентимерова Елизавета Флориановна (ок. 1817 - не ранее 1890) // Русские писатели. 18001917. Биографический словарь / Гл. ред. П. А. Николаев. М.: Большая российская энциклопедия, 2007. Т. 5. С. 580-581.

6. Ермоленко Г. Н. Французские военнопленные 1812 года на Смоленщине // Край Смоленский. 2002. № 5-6. С. 26-33.

7. Журнал исходящих документов Канцелярии смоленского гражданского губернатора. 1831 г. // Государственный архив Смоленской области. Ф. 1. Оп. 1.Д. 33.

8. Записки графа М. Д. Бутурлина / Науч. ред. М. А. Полякова. В 2 т. Т. ІІ. М.: Русская усадьба, 2006. 543 с.

9. Карташов В. С. Судьба Доминика де ла Флиза // Эпоха 1812 года. Исследования. Источники. Историография. Вып. IV / Труды ГИМ. Вып. 147. М., 2005. С. 80-81.

10. Макарова Н. В. Жизнь российских сословий в эпоху правления Николая I. М.: Экон-информ, 2012. 393 с.

11. Месяцеслов с росписью чиновных особ, или общий штат Российской империи, на лето от Рождества Христова 1821. Ч. 1. СПб., 1821.

12. Месяцеслов с росписью чиновных особ, или общий штат Российской империи, на лето от Рождества Христова 1822. Ч. 1. СПб., 1822.

13. Месяцеслов с росписью чиновных особ, или общий штат Российской империи, на лето от Рождества Христова 1823. Ч. 1. СПб., 1823.

14. Месяцеслов с росписью чиновных особ, или общий штат Российской империи, на лето от Рождества Христова 1824. Ч. 1. СПб., 1824.

15. Месяцеслов с росписью чиновных особ, или общий штат Российской империи, на лето от Рождества Христова 1825. Ч. 1. СПб., 1825.

16. Миловидов Б. П. Военнопленные медики Великой армии // Отечественная война 1812 года и российская провинция в событиях, человеческих судьбах и музейных коллекциях: Материалы Всероссийской научной конференции. Вып. XIV. Малоярославец, 2006. С. 177-189.

17. Миловидов Б. П. Жизнь и судьба военнопленного врача Генриха фон Рооса // Бородино и наполеоновские войны: Битвы. Поля сражений. Мемориалы. Можайск, 2008. С. 307-317.

18. О принятии подданства. 1828-1852 гг. // Государственный архив Российской Федерации. Ф. 109. Оп. 227. Д. 16.

19. Овер Александр Иванович // Биографический словарь профессоров и преподавателей Императорского Московского университета. 1755-1855. T. II. М., 1855. С. 160-174.

20. По отношению Главнокомандующего в Санкт-Петербурге. О желающих в подданстве России пленных. 7 апреля 1813 г. - 29 января 1815 г. // Государственный архив Смоленской области. Ф. 1. Оп. 1. Д. 183. 1813 г.

21. Полное собрание законов Российской империи. Собрание 1-е. Т. XXXII.

22. Полное собрание законов Российской империи. Собрание 2-е. Т. II. 


\section{Исторический журнал: научные исследования № 4 (22) • 2014}

\section{DOI: $10.7256 / 2222-1972.2014 .4 .13937$}

23. Полное собрание законов Российской империи. Собрание 2-е. T. III.

24. Полное собрание законов Российской империи. Собрание 2-е. T. IV.

25. Полное собрание законов Российской империи. Собрание 2-е. T. VII.

26. Полное собрание законов Российской империи. Собрание 2-е. T. XXVI. Ч. 2.

27. Полное собрание законов Российской империи. Собрание 2-е. T. XXXII.

28. Помогал, «не различая звания и состояния». Судьба французского лекаря Франца Валя в России / Публикацию подготовила А. В. Тихонова // Исторический архив. 2010. № 6. С. 154-158.

29. Потрашков С. В. Военнопленные Великой армии в Слободско-Украинской губернии // Отечественная война 1812 года. Источники. Памятники. Проблемы: Материалы VII Всероссийской научной конференции, 1998 г. Бородино, 1999. C. $143-149$.

30. Прошения учителей и лиц разных сословий о допуске к испытаниям и выдаче свидетельств на звание учителей, о предоставлении вакантных должностей в училищах и по другим вопросам. 21 марта 1838 г. - 11 декабря 1838 г. // Государственный архив Смоленской области. Ф. 45. Оп. 1. Д. 251.

31. Свод законов Российской империи. T. XIV. СПб., 1832.

32. Сентимер Ф. Еще нечто о холере. М.: Университетская типография, 1833. 28 с.

33. Сентимер Ф. Холера излечима! Сочинение д-ра медицины Флориана Сентимера, для врачей и не для врачей. Киев, 1872.18 c.

34. Смоленск. Известия // Смоленские губернские ведомости. 1838. № 25 (27 июня).

35. Уден Федор Карлович // Энциклопедический словарь Ф. А. Брокгауза и И. А. Ефрона. СПб., 1902. Т. XXXIVa. С. 580.

36. Формулярные списки за 1853 г. // Государственный архив Смоленской области. Ф. 754. Оп. 2. Д. 89.

37. Формулярный список А. И. Дурлахера, рославльского городового врача. 1850-1859 гг. // Государственный архив Смоленской области. Ф. 2. Оп. 42. Д. 664.

38. Формулярный список А. Ф. Селю, поречского уездного врача. 1843-1846 гг. // Государственный архив Смоленской области. Ф. 2. Оп. 42. Д. 1981.

39. Формулярный список Ф. Сентимера. 1824 г. // Российский государственный исторический архив. Ф. 1343. Оп. 29. Д. 2457. 1854 г.

40. Хомченко С. Н. Военнопленные армии Наполеона в Казанской губернии в 1812-1814 гг. // Бородино и наполеоновские войны: Битвы. Поля сражений. Мемориалы: Материалы II Международной научной конференции (Бородино, 3-5 сентября 2007 г.) / Сост. А. В. Горбунов. Можайск, 2008. С. 293-306.

41. Циркуляры, сообщения и т. д. министерств и иных высших правительственных учреждений на имя Смоленского гражданского губернатора на 1814 г. 30 июня 1814 г. - 17 декабря 1814 г. // Государственный архив Смоленской области. Ф. 1. Оп. 1. Д. 240. 1814 г.

42. Циркуляры, сообщения и т. д. министерств и иных высших правительственных учреждений на имя Смоленского гражданского губернатора на 1814 г. 18 декабря 1813 г. - 19 июня 1814 г. // Государственный архив Смоленской области. Ф. 1. Оп. 1. Д. 241.1814 г.

\section{References (transliterated):}

1. Alfavit del pribyvshikh v Rossiyu inostrantsev. 1827-1830 gg. // Gosudarstvennyi arkhiv Rossiiskoi Federatsii. F. 109. Op. 226. D. 7.

2. Baranov A. A. Meditsinskaya sluzhba rossiiskoi armii. Meditsinskaya sluzhba frantsuzskoi armii // Otechestvennaya voina 1812 goda: Entsiklopediya / Ruk. avtorskogo kollektiva V. M. Bezotosnyi. M.: ROSSPEN, 2004. S. 449-452.

3. Budko A. A. Istoriya meditsiny Sankt-Peterburga XIX - nachala KhKh v. SPb.: Nestor-Istoriya, 2010. $400 \mathrm{~s}$.

4. Bush Ivan Fedorovich // Mirskii M. B. Meditsina Rossii XVI-XIX vekov. M.: ROSSPEN, 1996. S. 181-188.

5. Evseeva M. K. Sentimer, Sentimerova Elizaveta Florianovna (ok. 1817 - ne ranee 1890) // Russkie pisateli. 1800-1917. Biograficheskii slovar' / Gl. red. P. A. Nikolaev. M.: Bol'shaya rossiiskaya entsiklopediya, 2007. T. 5. S. 580-581.

6. Ermolenko G. N. Frantsuzskie voennoplennye 1812 goda na Smolenshchine // Krai Smolenskii. 2002. № 5-6. S. 26-33.

7. Zhurnal iskhodyashchikh dokumentov Kantselyarii smolenskogo grazhdanskogo gubernatora. 1831 g. // Gosudarstvennyi arkhiv Smolenskoi oblasti. F. 1. Op. 1. D. 33.

8. Zapiski grafa M. D. Buturlina / Nauch. red. M. A. Polyakova. V 2 t. T. II. M.: Russkaya usad'ba, 2006. 543 c.

9. Kartashov V. S. Sud'ba Dominika de la Fliza // Epokha 1812 goda. Issledovaniya. Istochniki. Istoriografiya. Vyp. IV / Trudy GIM. Vyp. 147. M., 2005. S. 80-81.

10. Makarova N. V. Zhizn' rossiiskikh soslovii v epokhu pravleniya Nikolaya I. M.: Ekon-inform, 2012. 393 s.

11. Mesyatseslov s rospis'yu chinovnykh osob, ili obshchii shtat Rossiiskoi imperii, na leto ot Rozhdestva Khristova 1821. Ch. 1. SPb., 1821.

12. Mesyatseslov s rospis'yu chinovnykh osob, ili obshchii shtat Rossiiskoi imperii, na leto ot Rozhdestva Khristova 1822. Ch. 1. SPb., 1822.

13. Mesyatseslov s rospis'yu chinovnykh osob, ili obshchii shtat Rossiiskoi imperii, na leto ot Rozhdestva Khristova 1823. Ch. 1. SPb., 1823.

14. Mesyatseslov s rospis'yu chinovnykh osob, ili obshchii shtat Rossiiskoi imperii, na leto ot Rozhdestva Khristova 1824. Ch. 1. SPb., 1824.

15. Mesyatseslov s rospis'yu chinovnykh osob, ili obshchii shtat Rossiiskoi imperii, na leto ot Rozhdestva Khristova 1825. Ch. 1. SPb., 1825.

16. Milovidov B. P. Voennoplennye mediki Velikoi armii // Otechestvennaya voina 1812 goda i rossiiskaya provintsiya v sobytiyakh, chelovecheskikh sud'bakh i muzeinykh kollektsiyakh: Materialy Vserossiiskoi nauchnoi konferentsii. Vyp. XIV. Maloyaroslavets, 2006. S. 177-189. 
17. Milovidov B. P. Zhizn' i sud'ba voennoplennogo vracha Genrikha fon Roosa // Borodino i napoleonovskie voiny: Bitvy. Polya srazhenii. Memorialy. Mozhaisk, 2008. S. 307-317.

18. O prinyatii poddanstva. 1828-1852 gg. // Gosudarstvennyi arkhiv Rossiiskoi Federatsii. F. 109. Op. 227. D. 16.

19. Over Aleksandr Ivanovich // Biograficheskii slovar' professorov i prepodavatelei Imperatorskogo Moskovskogo universiteta. 1755-1855. T. II. M., 1855. S. 160-174.

20. Po otnosheniyu Glavnokomanduyushchego v Sankt-Peterburge. 0 zhelayushchikh v poddanstve Rossii plennykh. 7 aprelya 1813 g. - 29 yanvarya 1815 g. // Gosudarstvennyi arkhiv Smolenskoi oblasti. F. 1. Op. 1. D. 183.1813 g.

21. Polnoe sobranie zakonov Rossiiskoi imperii. Sobranie 1-e. T. XXXII.

22. Polnoe sobranie zakonov Rossiiskoi imperii. Sobranie 2-e. T. II.

23. Polnoe sobranie zakonov Rossiiskoi imperii. Sobranie 2-e. T. III.

24. Polnoe sobranie zakonov Rossiiskoi imperii. Sobranie 2-e. T. IV.

25. Polnoe sobranie zakonov Rossiiskoi imperii. Sobranie 2-e. T. VII.

26. Polnoe sobranie zakonov Rossiiskoi imperii. Sobranie 2-e. T. XXVI. Ch. 2.

27. Polnoe sobranie zakonov Rossiiskoi imperii. Sobranie 2-e. T. XXXII.

28. Pomogal, «ne razlichaya zvaniya i sostoyaniya». Sud'ba frantsuzskogo lekarya Frantsa Valya v Rossii / Publikatsiyu podgotovila A. V. Tikhonova // Istoricheskii arkhiv. 2010. № 6. S. 154-158.

29. Potrashkov S. V. Voennoplennye Velikoi armii v Slobodsko-Ukrainskoi gubernii // Otechestvennaya voina 1812 goda. Istochniki. Pamyatniki. Problemy: Materialy VII Vserossiiskoi nauchnoi konferentsii, 1998 g. Borodino, 1999. S. 143-149.

30. Prosheniya uchitelei i lits raznykh soslovii o dopuske k ispytaniyam i vydache svidetel'stv na zvanie uchitelei, o predostavlenii vakantnykh dolzhnostei v uchilishchakh i po drugim voprosam. 21 marta 1838 g. - 11 dekabrya 1838 g. // Gosudarstvennyi arkhiv Smolenskoi oblasti. F. 45. Op. 1. D. 251.

31. Svod zakonov Rossiiskoi imperii. T. XIV. SPb., 1832.

32. Sentimer F. Eshche nechto o kholere. M.: Universitetskaya tipografiya, 1833. 28 s.

33. Sentimer F. Kholera izlechima! Sochinenie d-ra meditsiny Floriana Sentimera, dlya vrachei i ne dlya vrachei. Kiev, 1872.18 s.

34. Smolensk. Izvestiya // Smolenskie gubernskie vedomosti. 1838. № 25 (27 iyunya).

35. Uden Fedor Karlovich // Entsiklopedicheskii slovar' F. A. Brokgauza i I. A. Efrona. SPb., 1902. T. XXXIVa. S. 580.

36. Formulyarnye spiski za 1853 g. // Gosudarstvennyi arkhiv Smolenskoi oblasti. F. 754. Op. 2. D. 89.

37. Formulyarnyi spisok A. I. Durlakhera, roslavl'skogo gorodovogo vracha. 1850-1859 gg. // Gosudarstvennyi arkhiv Smolenskoi oblasti. F. 2. Op. 42. D. 664.

38. Formulyarnyi spisok A. F. Selyu, porechskogo uezdnogo vracha. 1843-1846 gg. // Gosudarstvennyi arkhiv Smolenskoi oblasti. F. 2. Op. 42. D. 1981.

39. Formulyarnyi spisok F. Sentimera. 1824 g. // Rossiiskii gosudarstvennyi istoricheskii arkhiv. F. 1343. Op. 29. D. 2457. 1854 g.

40. Khomchenko S. N. Voennoplennye armii Napoleona v Kazanskoi gubernii v 1812-1814 gg. // Borodino i napoleonovskie voiny: Bitvy. Polya srazhenii. Memorialy: Materialy II Mezhdunarodnoi nauchnoi konferentsii (Borodino, 3-5 sentyabrya 2007 g.) / Sost. A. V. Gorbunov. Mozhaisk, 2008. S. 293-306.

41. Tsirkulyary, soobshcheniya i t. d. ministerstv i inykh vysshikh pravitel'stvennykh uchrezhdenii na imya Smolenskogo grazhdanskogo gubernatora na 1814 g. 30 iyunya 1814 g. - 17 dekabrya 1814 g. // Gosudarstvennyi arkhiv Smolenskoi oblasti. F. 1. Op. 1. D. 240.1814 g.

42. Tsirkulyary, soobshcheniya i t. d. ministerstv i inykh vysshikh pravitel'stvennykh uchrezhdenii na imya Smolenskogo grazhdanskogo gubernatora na 1814 g. 18 dekabrya 1813 g. - 19 iyunya 1814 g. // Gosudarstvennyi arkhiv Smolenskoi oblasti. F. 1. Op. 1. D. 241.1814 g. 